\title{
Az ÉFOÉSZ és tagszervezeteinek törekvései a könnyen érthető kommunikáció területén
}

\begin{abstract}
A tanulmányban - szemle jelleggel - az ÉFOÉSZ és három tagszervezete innovációs törekvéseinek a bemutatására kerül sor. Célom annak bemutatása, hogy mi történt az elmúlt évtizedekben a könnyen érthető kommunikáció területén, illetve milyen tényezők segítik és akadályozzák a módszer hazai elterjesztését. Kitérünk a jövőre vonatkozó tervekre is.

Kulcsszavak: könnyen érthető kommunikáció, innováció, Értelmi Fogyatékossággal Élők és Segítőik Országos Érdekvédelmi Szövetsége (ÉFOÉSZ)
\end{abstract}

\section{BeVEZető}

A világon minden embernek joga van ahhoz, hogy a társadalom aktív tagja legyen. Ez a jog magában foglalja az információhoz való hozzáférés jogát is, legyen szó bármely területröl: irodalomról, kultúráról vagy akár politikáról. Fontos, hogy megfelelő minőségü és mennyiségű információt birtokoljunk egy adott témával kapcsolatban. Ennek érdekében az emberek számára az információt érthető formában kell felkínálni. Így tudnak adekvát döntéseket hozni és a társadalom aktív tagjává válni (Farkasné \& Graf-Jaksa, 2009).

A könnyen érthető kommunikáció (KÉK) egy olyan kommunikációs forma, amely nem csak az értelmi sérült emberek életét könnyíti meg. Gondoljunk a mindennapi életre: nap mint nap találkozunk olyan helyzetekkel, ahol jól jönne, ha valaki elmondaná röviden és érthetően, hogy miről van szó. llyen eset például, ha hivatalos ügyeket szeretnénk intézni. Gyakran olyan bonyolult módon megfogalmazott dokumentumokkal találkozhatunk, amelyeket átlagos nyelvhasználóként is nehéz megérteni.

Képzeljük el az ügyintézést például egy idegen nyelvű országban. Vajdasági magyarként megtapasztaltam, hogy az érthető kommunikáció valamennyiünk életét megkönnyítheti. Nekem a magyar nyelv az anyanyelvem, de az ügyeket szerb nyelven kell intéznem. Szükség van tehát arra, hogy a könnyen érthető kommunikáció módszere ismertté váljon.

Tekintettel arra, hogy a Fogyatékosság és Társadalom című folyóirat jelen tematikus száma a könnyen érthető kommunikációval foglalkozik, a tanulmányban nem térek ki a fogalom meghatározására, a könnyen érthető kommunikációval kapcsolatos elméleti ismeretek összefoglalására.

Magyarországon az Értelmi Fogyatékossággal Élők és Segítőik Országos Érdekvédelmi Szövetsége játszott úttörő szerepet a könnyen érthető kommunikáció elterjesztésében (Farkasné Gönczi \& Graf-Jaksa, 2009). Ezért döntöttem úgy, hogy ezen civil szervezet munkásságát mutatom be ebben a cikkben. A továbbiakban röviden bemutatom az Értelmi Fogyatékossággal Élők és Segítőik Országos Érdekvédelmi 
Szövetségét, a bemutatásra választott civil szervezetet. Ezt követően szeretnék megrajzolni egy térképet, amelyen igyekszem láthatóvá tenni az ÉFOÉSZ és néhány tagszervezetének a könnyen érthető kommunikáció területén végzett munkásságát. A térkép megrajzolásához szükséges információk összegyüjtése érdekében interjút készítettem az alábbi személyekkel, akik hozzájárultak a név közléséhez:

1. az ÉFOÉSZ központi irodájából

a) Bercse László önérvényesítő, az ÉFOÉSZ társelnöke,

b) Czakó Tibor szakmai referens,

c) Sallai Ilona önérvényesítö, érdekvédelmi tanácsadó,

2. Bács-Kiskun megyéből Melcher Györgyné, a megyei szervezet elnöke,

3. Békés megyéböl Schriffertné Locskai Henriett, a megyei szervezet elnöke,

4. Csongrád-Csanád megyéböl Jenei Klára, a megyei szervezet elnöke,

5. Komárom-Esztergom megyéből Szegedi Erika, a megyei szervezet elnöke.

\section{Az ÉRTELMI FogYATÉKOSSÁGgAL ÉLŐK ÉS SEGÍTŐIK ORSZÁGOS ÉRDEKVÉDELMI SZÖVETSÉGÉRŐL}

Az alábbi összefoglalást a szövetség honlapján található információk alapján készítettem.

Az Értelmi Fogyatékossággal Élők és Segítőik Országos Érdekvédelmi Szövetsége (továbbiakban: ÉFOÉSZ) 1981-ben alakult meg, szülői kezdeményezésre. Az elmúlt 40 év alatt országos lefedettségűvé vált, az értelmi sérült személyek érdekvédelmével foglalkozó szervezetek közül egyedüliként. Az ÉFOÉSZ országszerte jelenleg több mint 22 ezer egyéni, és nagyjából 100 jogi személy tagból áll.

Az ÉFOÉSZ célcsoportjai:

1. értelmi sérült személyek,

2. az értelmi sérült személyek családtagjai,

3. az értelmi sérült személyekkel foglalkozó szakemberek,

4. magánszemélyek, akik elfogadják a szövetség céljait.

5. az ügy iránt elkötelezett cégek és vállalatok.

Az ÉFOÉSZ küldetése, hogy a Magyarország területén élő értelmi sérült emberek és családtagjaik társadalmi hátrányait mérsékelje. Emellett fontos, hogy a célcsoportok érdekeit érvényesíteni, képviselni és védeni tudják. Kiemelt cél, hogy az értelmi sérült emberek élni tudjanak emberi és állampolgári jogaikkal, valamint a társadalmi integrációjuk sikeres, szociális biztonságuk és rehabilitációjuk biztosított legyen.

Az ÉFOÉSZ a Fogyatékossággal élő személyek jogairól szóló ENSZ egyezményben, valamint a Madridi Nyilatkozatban foglaltak megvalósításával elő kívánja segíteni az értelmi sérült emberek önrendelkezését, az önmagukért érzett felelősség egyidejü kialakítása mellett. Az ÉFOÉSZ összefogja az értelmi sérült emberek hazai szervezeteit, összehangolja ezen szervezetek tevékenységeit. Arra törekszenek, hogy elismertessék a szövetséget a kormányzati és parlamenti erőkkel, önkormányzati testületekkel (fogyatékosságügyi ENSZ egyezmény, 2006; Madridi Nyilatkozat, 2003). 
A szövetség központi, budapesti irodája - többek között - információk gyűjtésével és továbbításával, különböző kiadványok készítésével (kiemelt szerepet kapnak a könnyen érthető kiadványok), az elnökségi ülések elökészítésével és végrehajtásával, valamint a küldöttgyűlés elökészítésével és végrehajtásával foglalkozik.

\section{A KÖNNYEN ÉRTHETŐ KOMMUNIKÁCIÓ ÉS AZ ÉFOÉSZ}

Magyarországon az ÉFOÉSZ 2002-ben kezdett el foglalkozni a könnyen érthető kommunikációval. Ez nagyjából egybeesik az önérvényesítő mozgalom hazai kialakulásával is.

Ebben az időszakban magyarországi rendezvényeken is elkezdték használni a könnyen érthető segédanyagokat. Így például a konferenciák programját megfogalmazták könnyen érthetően. Kártyákat osztottak ki a résztvevők számára. Ezek három színből állnak - zöld, sárga és piros. A kártyák azt a célt szolgálják, hogy a használója jelezni tudja az előadások közben, ha túl gyors a tempó (sárga), illetve, ha valamit nem ért (piros), vagy ha valamivel egyetért (zöld).

Az ÉFOÉSZ egyre több könnyen érthető kiadványt adott ki. Az Inclusion Europe engedélyével több anyagot is magyarra fordítottak. A Szociális és Munkaügyi Minisztérium támogatásával elkészült az Országos Fogyatékosügyi Program és a fogyatékosságügyi ENSZ egyezmény könnyen érthető változata is. Annak érdekében, hogy az egyezmény bonyolult jogi szövegét az értelmi sérült emberek is megértsék, az ÉFOÉSZ elkészített egy munkafüzetet is, amelyben játékos és a szövegfeldolgozást segítő feladatokkal hozzák közelebb a szöveget az értelmi sérült személyekhez.

Ezt követően az ÉFOÉSZ-t több közintézmény, civil szervezet is megkereste azzal, hogy nyújtson nekik támogatást a honlapjuk akadálymentesítési koncepciójának kidolgozásával (Farkasné \& Graf-Jaksa, 2009).

A továbbiakban az ÉFOÉSZ munkatársaival készített interjúk tartalmát - a könynyen érthető kommunikáció magyarországi felhasználásának elterjesztéséhez kapcsolódó legfontosabb kérdések köré szerkesztve - ismertetem.

\section{A KÖNNYEN ÉRTHETŐ KOMMUNIKÁCIÓ HAZAI ELTERJESZTÉSE ÉRDEKÉBEN VÉGZETT TEVÉKENYSÉGEKRŐL}

\section{Milyen céljai vannak az ÉFOÉSZ-nak a könnyen érthető kommunikáció hazai elterjesztése érdekében? Mit tesznek a kitüzött célok elérése érdekében? Milyen akadályok kor- látozzák a célok elérését?}

Az ÉFOÉSZ-nak az a célja, hogy az értelmi sérült emberek számukra érthető információkhoz jussanak. Ez kell ahhoz, hogy önálló életet tudjanak élni, önálló döntéseket tudjanak hozni, és felelős felnőtt emberként tudjanak élni. A mi célunk az, hogy ezt 
a módszert minél több emberrel megismertessük, föleg azokkal, akik a célcsoporttal bármilyen formában érintkeznek (szakemberek, segítők, szülők). Ez szükséges ahhoz, hogy jól tudják segíteni az általuk támogatott személyeket. A törvények és rendeletek segíthetnek abban, hogy garanciákat kapjunk, vagy érvényesíteni tudjuk a jogokat. A fogyatékosságügyi ENSZ egyezményben van egy cikk, ami a hozzáférhetőségről szól. Ott nevesítve van a könnyen érthető kommunikáció. A magyar jogszabályokban azonban még kevés helyen találkozhatunk a könnyen érthető kommunikációval mint módszerrel. A könnyen érthető kommunikáció kizárólag az Országos Fogyatékosságügyi Programban szerepel, ez utóbbit határozatként, azaz egyedi aktusként fogadta el az Országgyülés. Egyébként nincsen a könnyen érthető kommunikációról külön jogszabály. Ha összehasonlítjuk az értelmi fogyatékos személyek helyzetét például a siket személyek helyzetével, nekik van saját jelnyelvi törvényük. Jó lenne, ha lenne a könnyen érthető kommunikációról szóló törvény is, ahogy más országokban (például Németországban vagy Ausztriában). Ez tehát nagyon nagy akadálynak számít (Czakó Tibor).

Sallai Ilona hozzátette, hogy ők értelmi sérült személyekként sokszor kirekesztődnek a világból, mert nem értik meg azokat az információkat, amelyeket nekik szánnak. Ez azért történik, mert általában szakszavakkal vagy bonyolultan, hosszú mondatokban fogalmaznak. Azért tartja jó módszernek a könnyen érthető kommunikációt, mert az segít nekik az információk könnyebb megértésében. Kiemelte, hogy a szöveget nem lebutítva szeretnék megkapni, hanem a lényeget kiemelve, de mégis az ő képességeikhez igazítva. Az akadályok között Sallai llona is említette azt, hogy hiába csatlakozott Magyarország a fent említett ENSZ egyezményhez, valójában az emberek inkább a fizikai akadálymentesítés fogalmát ismerik, kevésbé az infokommunikációs akadálymentesítését. Megerősítette, hogy szeretnék elérni, hogy minél hamarabb legyen jogszabály a könnyen érthető kommunikációról.

Bercse László kiemelte, hogy például Németországban vannak könnyen érthető blogok; ezeket maguk az önérvényesítők szerkesztik, illetve vannak újságok is, amelyeket lefordítanak könnyen érthető nyelvi szintre. Szeretné elérni, hogy Magyarországon is legyen erre lehetőség.

Jenei Klára szerint a Csongrád-Csanád megyei szervezet célja, hogy az értelmi sérült személyekhez és minél több érintett családhoz eljussanak. Vannak olyan családok, akik nincsenek a látókörükben. Emellett céljuk, hogy a különböző szociális intézményekben dolgozók is megismerjék a könnyen érthető kommunikációt. Véleménye szerint a társadalmi tudatformálásnak jó eszköze a könnyen érthető kommunikáció. El szeretnének jutni továbbá civil szervezetekhez, különböző, például egészségügyi intézményekhez, általános és középfokú iskolákba. Jenei Klára az akadályok között első helyen az ismeretlentől való félelmet említette. Az a tapasztalata, hogy sok esetben zárkózottak az emberek. Így nehéz bármilyen tanfolyamot, műhelymunkát vagy akár önérvényesítőkkel közös beszélgetést szervezni. Sok esetben az értelmi sérült személyek akadályokba ütköznek például vásárlás során, hiszen nehezebben megy nekik a pénzkezelés. A könnyen érthető kommunikációra, a könnyebb nyelvezetủ beszédre az ott dolgozók nem minden esetben nyitottak. Pedig ez megkönnyítené az értelmi sérült emberek életét.

Schriffertné Locskai Henriett elmondta, hogy számukra Békés megyében az az elsődleges cél, hogy minél több ember meg tudja ismerni a környező világot, el tudják látni napi feladataikat. Az ÉFOÉSZ munkatársai pedig próbálnak segíteni 
nekik az eligazodásban, tájékozódásban, és abban, hogy a mindennapjaikat minél önállóbban tudják élni. Ebben nagy szerepe van a könnyen érthető kommunikációnak. Amikor az akadályokról kérdeztem, válasza az volt, hogy meg kell keresniük és tanulniuk azokat az utakat, amelyekkel elérik a céljaikat. Ezt azonban kihívásnak és nem kifejezetten akadálynak fogják fel. Valójában először nekik is fel kell térképezniük azt, hogy milyen tudásra van szükség a könnyen érthető kommunikációhoz, amit aztán tovább tudnak adni.

Melcher Györgyné szerint fontos az, hogy az értelmi sérült emberek számára akadálymentes környezetet alakítsanak ki. Ök ugyanolyan emberek, ugyanolyan jogok illetik meg őket, mint bárki mást. A könnyen érthető kommunikáció terjesztésével kapcsolatban nem ütköznek semmilyen akadályba. Sőt, azt tapasztalják, hogy inkább támogatják őket, például a hatóságok is kérik, hogy szerezzenek be számukra könnyen érthető kiadványokat, illetve segítsenek az ilyen kiadványok létrehozásában.

Szegedi Erika elmondta, hogy megyei egyesületként az a feladatuk, hogy az értelmi sérült embereknek megadják a kommunikációs támogatást. Ezt az interneten keresztül terjesztett, illetve nyomtatott kiadványok útján biztosítják. Amikor az akadályokról kérdeztem, pozitívan állt a dolgokhoz: „Nincs olyan akadály, amit ne tudnánk átlépni, vagy elgördíteni magunk elől!"

\section{Mit tesz az ÉFOÉSZ a módszer népszerüsítése érdekében? Milyen eredményeket értek el eddig?}

Czakó Tibor szerint az ÉFOÉSZ munkásságából kiemelendő, hogy maguk is részt vettek a könnyen érthető kommunikáció európai irányelveinek a kidolgozásában. Ez volt az Európai Unió által támogatott, Pathways 1. nevű projekt, amit az európai ernyőszervezetként működő Inclusion Europe fogott össze. Kilenc ország érdekvédői dolgoztak együtt a programban. A program részeként megszervezték a képzők képzését is, amelynek keretében Bercse László is tanúsítványt szerzett. Bercse László már a sorstársainak is tartott képzést.

Czakó Tibor szerint a könnyen érthető kommunikáció nem csak az értelmi sérült embereknek lehet nagyon fontos, hanem bárki másnak, aki valamilyen oknál fogva nehezebben érti meg a hagyományosan megfogalmazott üzeneteket. Az index. hu információs portállal való együttműködésben az önkormányzati választások előtt például az ÉFOÉSZ munkatársai és az Index újságírói könnyen érthető cikkeket írtak a hírportálra. Valószínüleg az index.hu olvasói közül sokan szívesen fogadták ezeket a híreket. Az önkormányzati választások napján a folyamatosan frissülő percről percre rovatban néhány óránként könnyen érthető összefoglalók is megjelentek. Talán megértették az index.hu munkatársai a könnyen érthető üzenetek hasznosságát, amikor vállalkoztak az együttmüködésre.

Nagyon aktuális, hogy a koronavírus-járványról minden nap jelenik meg az ÉFOÉSZ Facebook oldalán és a honlapján egy könnyen érthető hírösszefoglaló. Van az ÉFOÉSZ-nak egy könnyen érthető blogja is. Ez utóbbit éppen az interjút adó Sallai Ilona, Czakó Tibor és Bercse László szerkesztik.

Van továbbá egy, az Európai Unió által finanszírozott EFOP pályázati programja is az ÉFOÉSZ-nak, meséli tovább Czakó Tibor. Az országban minden megyében és 
Budapesten létrehoztak egy-egy központot, ahol legalább egy önérvényesítő dolgozik, van, ahol kettő is. Az önérvényesítő munkatársaknak a szerződései és a munkaköri leírásai is könnyen érthető nyelven készültek el.

Czakó Tibor szerint nagyon fontos az is, hogy a módszerről tudjanak az érintett célcsoportot segítő emberek. Ezért szerveznek a szociális szakembereknek szóló képzéseket. Vannak továbbá egyetemeken tartott képzéseik is. Együttmüködnek az SZTE JGYPK Gyógypedagógus-képző Intézetével és az ELTE Bárczi Gusztáv Gyógypedagógiai Karral. Így a gyógypedagógia alapszakos hallgatók is megismerhetik ezt a módszert, és amikor elkezdenek a gyakorlatban dolgozni, akkor azonnal alkalmazni is tudják.

Fontos továbbá a társadalmi szemlélet formálása. Amikor Czakó Tibor és munkatársai konferencián előadást tartanak, akkor is könnyen érthető diasort készítenek, ha nem értelmi sérült emberek ülnek a hallgatóság soraiban. Így sokan megtapasztalhatják a könnyen érthető prezentáció külalakját és tartalmi felépítését.

Czakó Tibor megerősítette azt, hogy az önérvényesítő csoport müködését kiemelten fontosnak tartják. Minden anyagot, amit nekik szánnak, könnyen érthető módon készítenek el.

Sallai Ilona elmondta, hogy jártak a budapesti Csalogány EGYMI-ben is, ahol az önérvényesítésröl és a könnyen érthető kommunikáció fontosságáról beszéltek. Gyógypedagógusoknak tartották az előadást annak érdekében, hogy útmutatást adjanak nekik a minél hatékonyabb kommunikációhoz. A Csalogány EGYMI-ben kisgyermekkortól felnőttkorig jelen vannak az értelmi sérült emberek. Ezért fontos az, hogy az érintettek szükségleteihez mérten tudják a gyógypedagógusok átadni az információkat.

Sallai llona beszélt arról is, hogy az ÉFOÉSZ keretein belül a könnyen érthető kommunikációt alkalmazzák például csoportfoglalkozásokon is. Fontosnak tartják, hogy az érintettek jogtudatosabbak legyenek, ezáltal az önérvényesítés ne legyen nekik nehéz. Mindemellett alkalmazzák még a honlapjuk készítésekor, projekteknél és kiadványok írásánál is.

Jenei Klára elmondta, hogy a Csongrád-Csanád megyei ÉFOÉSZ szervezetnek is vannak saját könnyen érthető kiadványaik, de a központi ÉFOÉSZ-tól is szoktak átvenni, és azokat is népszerüsítik. Mindemellett a másik oldalról is megközelítik a könnyen érthető kommunikációt - az érintettek oldaláról. Úgy gondolja, hogy fontos az értelmi sérült emberek megerősítése annak érdekében, hogy ők is oda merjenek menni másokhoz például segítséget kérni, vagy elmondani azt, hogy mi a problémájuk. Ahhoz viszont, hogy ezt meg tudják tenni, a kommunikációt gyakorolniuk kell. Nagyon sok olyan foglalkozást tartanak, ahol ezt helyezik a fókuszba. Jenei Klára szerint sokat segít az, ha vannak olyan önérvényesítők, akik ki mernek állni, és képviselik önmagukat és a társaikat is. Így példát mutatnak társaik számára is.

Jenei Klára szerint a Csongrád-Csanád megyei ÉFOÉSZ irodán belül mindig törekednek arra, hogy könnyen érthetően kommunikáljanak másokkal a mindennapok során. A szülőknek is tartottak már felkészítő képzést. Az elnökségi üléseken is rendszeresen előkerül ez a téma. Akikkel szorosabban együtt dolgoznak, velük mindig megbeszélik, hogy mit kellett volna esetleg másképp mondani, illetve munka közben is visszajeleznek egymásnak, kiegészítik egymást.

Schriffertné Locskai Henriett is mesélt a fent már említett EFOP pályázati programról. Ennek keretében 8 témában adtak ki könnyen érthető kiadványokat. A Békés 
megyei szervezet ezen témakörök mentén szervezett programokat a megye területén - többek között - szociális intézményekben. Az említett kiadványok ingyenesen letölthetők az efoesz.hu honlapról. Arra törekszenek, hogy a központi ÉFOÉSZ által kiadott könnyen érthető tájékoztatókat helyben minél hatékonyabban tudják felhasználni. Az elmúlt évben az egyik kolléganőjével könnyen érthető társasjátékot is fejlesztettek.

Melcher Györgyné a családoknak szervezett szabadidős rendezvényeket emelte ki. Ilyen például a nyári nyaraltatás a Szelidi-tó partján. Ilyenkor nagy hangsúlyt fektetnek a könnyen érthetőségre. Ez azt jelenti, hogy próbálnak a reggeli tornától kezdve a főzésig mindent közösen és a táborozók számára érthető módon végezni. Természetesen ezekbe a táborokba is magukkal viszik a könnyen érthető kiadványokat. Például a főzéshez kiválóan tudják használni a képekkel illusztrált szakácskönyveket. Emellett például a háztartási gépek üzemeltetését is a kiadványok segítségével tudják megtanítani.

Szegedi Erika elmondta, hogy a helyi önkormányzat nem csak támogatja a helyi ÉFOÉSZ-t, hanem együtt is müködnek. A helyi esélyegyenlöségi programban is szerepel legalább a könnyen érthető honlapok szükségessége. Az önkormányzattal közös céljuk, hogy városszerte könnyen érthető tájékoztató táblákat helyezzenek el. Így nemcsak számítógépen és interneten keresztül tudnak az érintettek könnyen érthető információkhoz jutni. Elmondta továbbá, hogy korábban tartottak már érzékenyítő tréningeket hatóságok részére is, például rendőrségnek, bíróságnak, kormányhivatal dolgozóinak. Saját maguk számára pedig nyelvi tolmácsolásra felkészítő továbbképzést szerveztek. Jelenleg azon dolgoznak, hogy a kialakult koronavírus-járvánnyal kapcsolatos tudnivalókról (például kézmosás, távolságtartás) könnyen érthető módon tájékoztassák az értelmi sérült embereket. Elsősorban azokat az értelmi sérült személyeket próbálják elérni, akik nem családban élnek.

Bercse László és Czakó Tibor rendszeresen vesznek részt külföldön nemzetközi konferenciákon és nemzetközi műhelymunkákban, ahol mindig könnyen érthetően kommunikálnak egymással. Bercse László az EPSA (Európai Önérvényesítő Platform) elnöke.

Czakó Tibor ehhez hozzátette, hogy az EPSA-nak háromhavonta jelenik meg könnyen érthető hírlevele - az „Európa nekünk” („Europe for us”). Ez a hírlevél több nyelven is megjelenik, angolul írják Brüsszelben, amit több országban fordítanak le az adott országban használt anyanyelvre, így magyar nyelvre is. Az újságban a nemzetközi érdekvédő munkával, önérvényesítéssel kapcsolatos híreket közölnek. A korábbiakban már bemutatott képzéseken túl számos, a társadalmi tudatformálást szolgáló képzést szerveztek például bíróknak, rendőröknek. Az Európai Parlament tagjainak választási időszakában erről szóló könnyen érthető kiadványokat készítettek.

Sallai Ilona elmesélte, hogy Horváth Péter Lászlóval a németországi Hildesheim egyetemén jártak, ahol többek között a könnyen érthető kommunikációt kutatják. Itt egy konferencia keretében előadást tartottak a könnyen érthető kommunikáció participatív oktatásának tapasztalatairól. A május 5-i önálló életvitel nemzetközi napja alkalmából minden évben szerveznek rendezvényeket értelmi sérült emberekkel közösen. Ilyenkor is szükség van a könnyen érthetöségre.

Jenei Klára azt emelte ki, hogy sok civil szervezettel müködnek együtt, például a vak és gyengénlátó, halmozottan fogyatékos embereket képviselő civil szervezetek- 
kel. Velük közös programokat szerveznek, például kirándulásokat. Ilyen esetekben kölcsönös a társadalmi tudatformálás. Mindig beszélnek a könnyen érthető kommunikációról is, ami így egyre több emberhez is eljuthat. Igyekeznek a helyi önkormányzat felé is nyitni, illetve kapcsolatot teremteni. Tartottak már esélyegyenlőségi gálát, több nagyobb rendezvényt és fórumokat. llyenkor törekszenek a médianyilvánosság biztosítására. A helyi újságokban és a városi televízióban is kaptak már lehetőséget a szereplésre, így tudják a hírét vinni a könnyen érthető kommunikációnak.

A Melcher Györgyné által képviselt szervezet többek között a bajai Fogyatékosok Nappali Intézményébe vagy a kalocsai Értelmi Fogyatékosok Napközi Otthonába juttat el könnyen érthető kiadványokat, például orvosi vizsgálatokkal kapcsolatban (méhnyakrákszürésről, mellvizsgálatról). A cél az, hogy az értelmi sérült emberek is megismerjék és megértsék a preventív egészségügyi vizsgálatok fontosságát. Ugyanakkor tartottak már tájékoztatást a témáról olyan hivatalnokoknak is, akik kapcsolatban állhatnak értelmi sérült személyekkel. Azt javasolták a közintézmények képviselőinek, hogy ők is gondoskodjanak könnyen érthető kiadványokról. Fontos eredmény, hogy vannak már olyan hivatalok is, amelyek képviselői maguk kérik a segítséget az ÉFOÉSZ helyi szervezetétől a fordítások elvégzéséhez, illetve igénylik, hogy kaphassanak a központilag kiadott könnyen érthető kiadványokból.

Szegedi Erika is a kiadványok terjesztésében látja a lehetőséget, hiszen a megyében nagyon sok értelmi sérült személynek szolgáltatást nyújtó intézmény működik. Ezáltal egyre több helyre eljut a könnyen érthető kommunikáció, és hasznát is veszik a kiadványoknak. Ök is törekszenek arra, hogy a helyi önkormányzattal, a várossal, illetve más önkormányzatokkal is jó kapcsolatot ápoljanak. Közös törekvésük, hogy a kormányhivatalokban is elérhetővé váljanak a könnyen érthető kiadványok.

\section{Hol és milyen formában találkozhatunk a könnyen érthető kommunikációval az ÉFOÉSZ keretén kívül?}

Czakó Tibor a Nemzeti Fogyatékosságügyi és Szociálpolitikai Központot ajánlja figyelmünkbe. A Központ számos könnyen érthető kiadványt készít és terjeszt. Javasolta továbbá Farkasné Gönczi Rita honlapját, amely kifejezetten a könnyen érthető kommunikációval foglalkozik, és ahonnan ugyancsak sok könnyen érthető anyagot lehet letölteni. És végezetül tanácsolta a Down Alapítványt is.

Sallai Ilona a Szegedi Tudományegyetem Juhász Gyula Pedagógusképző Kar innovációjára hívta fel a figyelmet.

Schriffertné Locskai Henriett elsősorban a gyógypedagógiai köznevelési intézményeket emelte ki, illetve bizonyos integráló óvodákat és iskolákat. Úgy gondolja, hogy ezeken a helyeken különösen felkészültnek kell lenni a könnyen érthető kommunikációt illetően.

\section{ÖsSZEFOGLALÁs}

A könnyen érthető kommunikáció Magyarországon is fokozatosan, lépésröl lépésre terjed. Az ÉFOÉSZ és az ernyőszervezet tagszervezetei komoly erőfeszítéseket tesznek annak érdekében, hogy a könnyen érthető kommunikációról szóló tájékoz- 
tató előadásokkal, a könnyen érthető kommunikációra felkészítő képzésekkel, illetve könnyen érthető kiadványok készítésével és azok kiadásával hozzájáruljanak az értelmi sérült személyek minél önállóbb életviteléhez. Az ÉFOÉSZ hitelesen tudja képviselni a könnyen érthető kommunikáció ügyét, hiszen az értelmi sérült embereknek és az értelmi sérült emberekkel közösen szervezett események (például klubok, mühelyek, szabadidős tevékenységek, konferenciák stb.) nem is képzelhetők el a könnyen érthetö kommunikáció nélkül.

Bízom abban, hogy a tisztelt olvasó legalább alapszintű betekintést nyert a könynyen érthető kommunikáció gyakorlatának világába. Javaslom, hogy kísérjék figyelemmel ezt az innovatív munkát a beszélgetőtársak által javasolt, itt elérhető honlapok követésével.

Ezen a térképen most nem vált látható az ÉFOÉSZ valamennyi tagszervezetének munkája, és más civil szervezeti kezdeményezések bemutatására sem került sor. Ugyanakkor remélem, hogy a közeljövőben újabb (például szakdolgozati) kutatások születnek a témában, és ezek eredményeként egyre több törekvésről és alkalmazási területről informálódhatunk a könnyen érthető kommunikációval kapcsolatban.

\section{Ajánlott honlapok:}

a Down Alapítvány honlapja: https://www.downalapitvany.hu/node/337

az „Együtt Velünk - Önérvényesítés” honlap: http://egyuttvelunk.onervenyesites.hu/

az ÉFOÉSZ honlapja: https://efoesz.hu/

Farkasné Gönczi Rita honlapja: http://konnyenertheto.gonczirita.hu/

a Nemzeti Fogyatékosságügyi- és Szociálpolitikai Központ honlapja: https://fszk.hu/?s=könnyen+érthető

a „Könnyen Érthető Információs Központ létrehozása” projekt FB oldala: https://www.facebook.com/konnyenertheto

\section{Irodalom}

Fogyatékossággal élő személyek jogairól szóló ENSZ egyezmény, 2006

Farkasné Gönczi R. \& Graf-Jaksa É. (2009). Könnyen érthető kommunikáció. In Pandula A., Szatmári P., Vincze T., Farkasné Gönczi R. \& Graf-Jaksa É. (szerk.), Kommunikációs és információs technológiák és fogyatékosságügy. ELTE Bárczi Gusztáv Gyógypedagógiai Kar, Budapest. 80-100.

Madridi Nyilatkozat (2003). „A befogadó társadalom alapja a diszkrimináció-mentességgel párosuló pozitív cselekvés.” http://www.msmke.hu/tamogat/madnyil.pdf Letöltés ideje: 2020.04. 08.

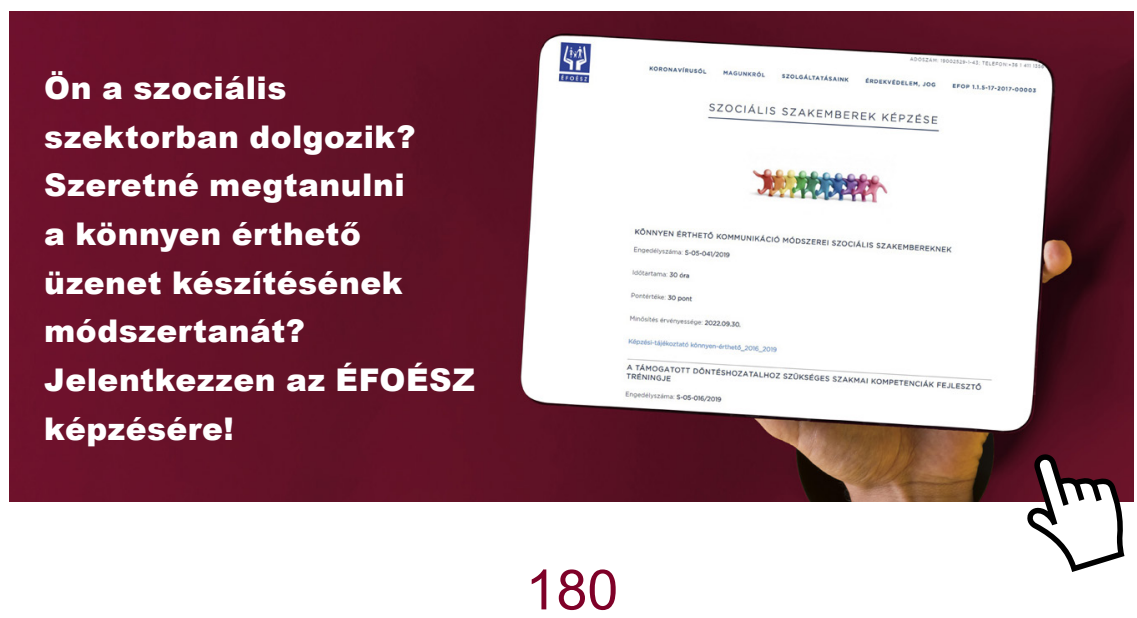

